\title{
Role of Interferon Gamma in COVID-19 Prevention - A Review
}

\section{IJCRR}

Section: Healthcare

Sci. Journal Impact

Factor: 6.1 (2018)

ICV: 90.90 (2018)

(c) (i) (8)

Copyright@IJCRR

\section{Tahreem Fathima ${ }^{1}$, M. P. Brundha ${ }^{2}$, D. Ezhilarasan ${ }^{3}$}

'Saveetha Dental College and Hospitals, Saveetha Institute of Medical and Technical Sciences (SIMATS), Saveetha University, Chennai-60oo77, India; ${ }^{2}$ Associate Professor, Department of Pathology, Saveetha Dental College and Hospitals, Saveetha Institute of Medical and Technical Sciences (SIMATS), Saveetha University, Chennai-60oo77, India; ${ }^{2}$ Lecturer, Department of Pharmacology, Saveetha Dental College and Hospitals, Saveetha Institute of Medical and Technical Sciences (SIMATS), Saveetha University, Chennai-6ooo77, India.

\section{ABSTRACT}

Aim: To study and determine the role of interferon-gamma in COVID-19 prevention.

Objective: The objectives include studying and understand the role of gamma interferon to cure or treat COVID-19 patients, to stop the spread of infection, and also to prevent future outbreaks.

MATERIALS AND METHODS- Review of literature by collecting and retrieving information from articles.

Discussion: The coronavirus disease is a highly transmittable and pathogenic viral infection caused by SARS CoV-2. Interferons are a family of proteins that releases several cells in response to the infection caused by viruses. Plasmacytoid dendritic cells are natural interferon producing cells. Interferons are involved in immune interactions and regulate viral mechanisms. Interferon-gamma binds to specific DNA elements. Patients suffering from nocturia, breast cancer, and diabetes mellitus are prone to cancer due to less immunity. Regenerative medicine for COVID-19 treatment can be helpful with the administration of umbilical cord-derived mesenchymal stem cells which could prevent lung inflammation. Interferons exert and affect target cells through the activation of cell surface receptors. Inflammation is a complex immune response to pathogens, damaged cells, or irritants and enables survival during infection or injury and also maintains tissue homeostasis. The Stat-1 dimer complex, also known as GAF (gamma activation factor), activates the transcription of IFN-y inducible genes through the GAS enhancer element. The innate production of interferon-gamma is a critical step in immunological defense mechanisms against viruses. The sources of gamma interferon in specific consist of activated natural killer cells, macrophages, and dendritic cells. The mediators of viral recognition that led to the production of interferons consist of a group of receptors located either in the cytoplasm or on the surface of endosomes; areas that allow these receptors to efficiently detect viral invasion. The virus is easily spreadable as it is highly contagious and spreads through close contact or droplets of infected people. This review highlights the role of gammainterferon in COVID-19 prevention.

Conclusion: The review highlights the role of gamma interferon in the prevention of COVID-19 to study and identify its role and mechanism to prevent and treat COVID-19. Interferons contain antiviral factors that produce fibroblasts after viral infections in which interferon-inducible PKR kinase catalyzes RNA degradation. Innate cell-mediated immunity through NK cells that stimulates specific cytotoxic immunity based on the recognition of cell surface-bound viral antigens expressed in major histocompatibility complex (MHC) proteins that activate macrophages which therefore activates the anti-viral and antimicrobial activity of interferon-gamma. Therefore, COVID-19 being a newly emerging virus, with no approved effective drug or vaccine, an intimate understanding of the role of interferons in prevention is essential to implement novel therapeutic strategies.

Key Words: Coronavirus, Interferon gamma, SARS- CoV-2, Interferon, COVID-19, Prevention

\section{INTRODUCTION}

The coronavirus disease (COVID-19) is a highly transmittable and pathogenic viral infection caused by SARS-CoV-2 (severe acute respiratory syndrome coronavirus-2). SARDS$\mathrm{CoV}-2$ is phylogenetically related to severe acute respiratory syndrome-like bat viruses therefore bats could be the primary reservoir. Coronaviruses belong to the family Coronaviridae in Nidovirales order ${ }^{1}$. Corona represents crown-like spikes on the outer surface of the virus, thus named coronavirus. The virion is an enveloped particle that contains a spike, membrane, and envelope proteins ${ }^{2}$. They are a large singlestranded RNA virus isolated from animal species. CoVs are positively stranded RNA viruses with a crown appearance ${ }^{3}$.

\section{Corresponding Author:}

Dr. M. P. Brundha, Associate Professor, Department of Pathology, Saveetha Dental College and Hospitals, Saveetha Institute of Medical and Technical Sciences, Saveetha University, Chennai-600077, India; Contact: +919884421482; Email: brundha.sdc@saveetha.com

ISSN: 2231-2196 (Print)

Received: 19.08 .2020
ISSN: $0975-5241$ (Online)

Revised: 16.09 .2020
Accepted: 12.10 .2020 
Coronaviruses cause ARDS (acute respiratory distress syndrome) which develops sepsis, pneumonia, aspiration of gastric content, and major trauma. The symptoms of corona include fever, cough, tiredness, shortness of breath, headache, chills, and sore throat. The virus is easily spreadable as it is highly contagious and spreads through close contact or droplets of infected people. The subgroups of the coronaviruses family are alpha, beta, gamma, and delta coronaviruses ${ }^{4}$. The coronavirus spike protein is a multifunctional molecular machine that mediates coronavirus entry into host cells viral entry relies on the interplay between virion and host cells $s^{5}$. Infection is initiated by the interaction of viral particles with specific proteins of the cell surface. After initially binding to the receptor, enveloped viruses fuse their envelopes into host cell membranes and deliver the nucleocapsid to target cells ${ }^{6}$. The dual play of spike protein is in entry by mediating receptor binding and membrane fusion. The fusion process involves a large conformational change of spike protein. Coronaviruses have a wide set of receptors that trigger fusion. The important role of spike protein is cell tropism. Coronaviruses are capable of adapting to new environments through mutations and recombination with ease in a programmed manner to alter host range and tissue tropism efficiently ${ }^{7}$. Among the four general or subgroups of coronaviruses, alpha and beta coronaviruses infect mammals, gamma coronaviruses infect avian species and delta coronaviruses infect both mammalian and avian species. When the first $\mathrm{CoV}$ receptor is identified, it binds to the adhesion molecule CEACAM1 (Carcinoembryonic antigen-related cell adhesion molecule-1) to infect cells ${ }^{8}$. IL-8 causes inflammation of the lungs and leads to fever, fibrosis, and respiratory complications infecting the host. Virus, toll-like receptors (TLRs), and pro-IL1 have inflammasome cells that affect innate adaptive immune system-specific immune responses ${ }^{9}$. Replication of RNA viruses could generate mutations due to low proofreading ability of RNA-dependent RNA polymerase (RDRP) and the genome variations generated by viral RNA-dependent RNA polymerase (RDRP) that leads to emerging viruses being adapted to host cells ${ }^{10}$. Molecular signals, receptors, and transcription control systems are the major factors that contribute to the development of the tooth, and interference in these factors could lead to development anomalies as COVID-19 causes disturbances in these factors $^{11}$. COVID-19 damages hemoglobin which impairs the ability of red blood cells to transport oxygen throughout the body, affecting the lungs leading to Acute Respiratory Distress Syndrome ${ }^{12}$. To prevent the spread of corona appropriate precautions must be taken such as cleaning hands, use of masks and gloves, maintaining a safe distance, staying in the eyes, or touching the nose. Personal protective equipment (PPE) is used to create a protective barrier between doctors and COVID patients ${ }^{13}$. As of now, the prophylaxis for prevention or action against corona is in the process but some antiviral drugs have been used to treat COVID-19 patients that include antimalarial drugs that disrupt the virus replication and cytokine storm such as chloroquine ${ }^{14}$. Also, untreated polycystic ovaries along with fibroid can lead to cancer and cancer patients are more prone to COVID-19 15,16,17. Patients suffering Hansen's disease are also more prone to COVID as this infection affects the upper respiratory tract as well as the eye ${ }^{18,19}$. COVID-19 not only affects the respiratory tract but it also shows symptoms in the eyes causing conjunctivitis like stye ${ }^{20}$. Patients suffering from nocturia, breast cancer, and diabetes mellitus are prone to cancer due to less immunity, ${ }^{18,19,20,21}$. Regenerative medicine for COVID-19 treatment can be helpful with the administration of umbilical cord-derived mesenchymal stem cells which could prevent lung inflammation ${ }^{22}$. The buccal smear is useful for diagnosing Malignancy, Fungal infection, Viral infection and Vesiculobullous dermatoses and so it could be used to detect COVID-19 ${ }^{23}$

\section{INTERFERON GAMMA IN COVID-19}

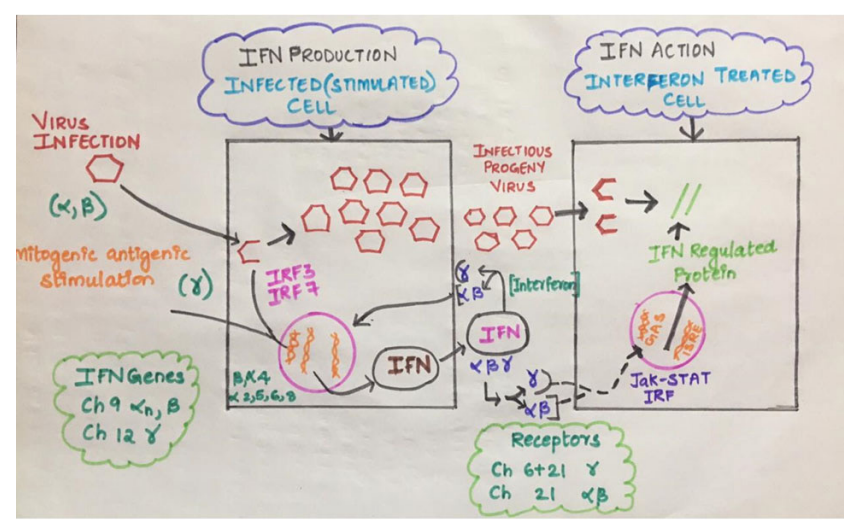

Figure 1: Antiviral actions of Interferon (Samuel 2001).

\section{Structure of Interferon}

Interferons are a family of proteins that are released by a variety of cells in response to infections caused by viruses ${ }^{24}$. They are classified based on nucleotide sequence interaction with specific receptors, chromosomal location, structure, and physicochemical properties ${ }^{25}$. Interferons are ubiquitous cytokines produced by all mononuclear cell types. There are 3 major classes of interferons: Type-1 or non-immune interferons that consist alpha produced by leukocytes and interferon-beta produced by fibroblasts, Type II or immune interferon is gamma which produces NK cells and T- cells, Type III are Lamba interferons ${ }^{26}$. Toll-like receptors (TLRs) on cell membranes and endosomes recognize viruses and other microorganisms. Interferon-gamma is an activated Tlymphocyte and natural killer cell that was described as an antiviral agent ${ }^{27}$. IFN gamma exhibits pleiotropic biological activities. Different classes of interferon produced different cell types under action different inducers ${ }^{28}$. Interferons exert 
and affect target cells through the activation of cell surface receptors ${ }^{29}$.

\section{Sources of Interferon}

Interferons are produced from plasmacytoid dendritic cells which are the natural interferon producing cells due to their unique molecular adaptations to nucleic acid-sensing and the ability to produce high amounts of interferons ${ }^{30,31}$. Interferons have antiviral factors that produce fibroblasts after viral infections ${ }^{32}$. Cytokines cells in interferon play a role in innate adaptive immunity by triggering Janus kinase (JAK) which signals transducer which is in turn activator of transcription signaling transduction ${ }^{33}$. Pleiotropic cytokines play a role in cell growth regulation ${ }^{34}$ and modulators of innate and adaptive immune responses ${ }^{3536}$.

The innate production of interferon-gamma is a critical step in immunological defense mechanisms against viruses. The sources of gamma interferon in specific consist of activated natural killer cells, macrophages, and dendritic cells ${ }^{37}$. Type 1 interferons, such as IFN- $\alpha$, are produced in large quantities by activated plasmacytoid dendritic cells (pDCs) and are particularly important in resistance to virus infections. The inflammatory cytokine IFN- $\gamma$ is produced in large quantities by Th1 effector CD4 T cells, by CD8 T cells, and by natural killer (NK) cells. Type 1 interferons help activate the conventional dendritic cells (cDCs) which are needed to initiate primary T-cell responses. IFN- $\gamma$ itself is needed to initiate the differentiation of activated T cells toward the IFN- $\gamma$-producing Th1 state ${ }^{38}$. Thus, the production of relatively small amounts of interferons by minor cell populations could be important in the early stages of immune responses. Dendritic cells can produce IFN- $\gamma$ when stimulated with interleukin 12 (IL-12) and IL-18.

\section{Functions of Interferon in Chronic Inflamma- tion and Infections}

Inflammation is a complex immune response to pathogens, damaged cells, or irritants which enables survival during infection or injury and also maintains tissue homeostasis ${ }^{39}$. In response to an infection, a cascade of signals leads to the recruitment of inflammatory cells (neutrophils and macrophages), which produce cytokines and chemokine ${ }^{40}$. The inflammasome is a multiprotein complex, which initiates cleavage of pro-inflammatory cytokines IL-1 $\beta$ and IL-18 into active forms ${ }^{41}$. Interferons (IFNs) and inflammatory cytokines are crucial molecules that influence cellular, tissue, and global physiological functions. Immune cells (macrophages, dendritic cells) recognize pathogen-associated molecular patterns (PAMPs) and endogenous danger-associated molecular patterns (DAMPs) ${ }^{42}$. Pattern recognition receptors (PRRs) detect bacterial and viral PAMPs and also recognize DAMPs endogenous molecules, released by dying or damaged cells ${ }^{43}$. Interferons interact with target cells. Interferons are in- volved in immune interactions and also inducers, regulators, effectors of innate adaptive immunity that cause antiviral mechanisms ${ }^{44}$. RNA degradation is catalyzed by interferoninducible PKR kinase ${ }^{45}$. Alteration of T-helper cells produces responses to inhibit the growth of the cell and promote apoptosis that induces an antiviral state in uninfected cells ${ }^{46}$. Interferon-gamma is the primary activator of macrophages ${ }^{47}$ that stimulates natural killer cells and neutrophils ${ }^{48}$. Virusspecific T-memory cells are a major source of gamma interferon in the prevention of viruses ${ }^{49}$. Interferon-gamma mediated by the induction of cellular products interferes with microbial metabolism ${ }^{50}$. Cellular responses to interferongamma are mediated by heterodimeric cell surface receptors which activate downstream signal transduction cascades ultimately leading to regulation of gene expression ${ }^{51}$. Type I- IFNs are protective in acute viral infections; however, in bacterial infections, they could have either protective or deleterious roles. Type I- IFNs are induced by ssRNA, dsRNA, and cytosolic DNA from viruses or bacteria.

\section{Mechanism of Interferon}

Coronavirus is susceptible to Type I interferon ${ }^{52}$. The interferon response and maximal virus replication ${ }^{53}$. The mediators of viral recognition that led to the production of interferons consist of a group of receptors located either in the cytoplasm or on the surface of endosomes; areas that allow these receptors to efficiently detect viral invasion ${ }^{54}$. Interferons exert their actions through cognate cell surface receptors that are largely species-specific. IFN- $\gamma$ plays an important role in both innate and adaptive immunity ${ }^{55}$. It stimulates innate cell-mediated immunity through NK cells and stimulates specific cytotoxic immunity based on the recognition of cell surface-bound viral antigens expressed in association with major histocompatibility complex (MHC) proteins that activate macrophages. Hence the immune responses mediated play an important role in the antiviral and antimicrobial actions of IFN- $\gamma$. The cells can be divided into three classes based on the pattern of cytokines produced following activation by antigens and mitogens.IL-12 and IL-18 are IFN- $\gamma$ inducing cytokines; IL-12 induction of IFN- $\gamma$ is dependent on caspase-1 processing of the IL-18 precursor protein ${ }^{56}$. IFN- $\gamma$ possesses unique immunoregulatory activities that are important in the innate host response against microbial infections and it also plays a role in mediating protection against viral infection, especially long-term control of viral infections. The various members of JAK and STAT families have distinct functions in cytokine signaling Receptor-associated JAKs are activated post binding of IFNs to their cognate multi-subunit transmembrane receptor. Of the known JAKs and STATs, the Jak-1, Jak-2, and Tyk-2 kinases and the Stat1 and Stat-2 transcription factors play central roles in mediating IFN-dependent biological responses, including induction of the antiviral state. IFN- $\gamma$ activates Jak-1 and Jak-2 kinases which lead to the phosphorylation and homodimeri- 
zation of the Stat-1 protein and also subsequent translocation to the nucleus. The Stat-1 dimer complex, known as GAF for gamma activation factor, activates the transcription of IFN- $\gamma$ inducible genes through the GAS enhancer element ${ }^{57}$.

\section{Future Scope}

Interferon plays a critical role in recognizing and eliminating pathogens and being the central effector of cell-mediated immunity it controls the antibacterial and antiviral functions. In reference to ${ }^{58,59}$, the use of these educational techniques could help in studying the causes of COVID-19.

\section{CONCLUSION}

The review highlights the role of gamma interferon in the prevention of COVID-19 to study and identify its role and mechanism to prevent and treat COVID-19. Interferons contain antiviral factors that produce fibroblasts after viral infections in which interferon-inducible PKR kinase catalyzes RNA degradation. Innate cell-mediated immunity through NK cells that stimulates specific cytotoxic immunity based on the recognition of cell surface-bound viral antigens expressed in major histocompatibility complex (MHC) proteins that activate macrophages which therefore activates antiviral and antimicrobial activity of interferon-gamma. Therefore, COVID-19 being a newly emerging virus, with no approved effective drug or vaccine, an intimate understanding of the role of interferons in prevention is essential to implement novel therapeutic strategies. Thus, treatments that reduce SARS-CoV load by several logs in infected individuals could enable more individuals to control, eliminate, and survive SARS-CoV infections. Combination IFN treatment, therefore, warrants further consideration as a treatment for SARS.

\section{ACKNOWLEDGEMENT}

I would like to thank the Department of General Pathology, Saveetha Dental College and Hospitals, Chennai for their constant support in this review.

\section{Conflict of Interest}

The authors have no conflict of interest.

\section{Source of Funding: Nil}

\section{REFERENCES}

1. Enjuanes L, Almazán F, Sola I, Zuñiga S. Biochemical aspects of coronavirus replication and virus-host interaction. Annu Rev Microbiol [Internet]. 2006;60:211-30. Available from: http:// dx.doi.org/10.1146/annurev.micro.60.080805.142157
2. Cascella M, Rajnik M, Cuomo A, Dulebohn SC, Di Napoli R. Features, Evaluation and Treatment Coronavirus (COVID-19). In: StatPearls [Internet]. Treasure Island (FL): StatPearls Publishing; 2020. Available from: https://www.ncbi.nlm.nih.gov/ pubmed $/ 32150360$

3. Prompetchara E, Ketloy C, Palaga T. Immune responses in COVID-19 and potential vaccines: Lessons learned from SARS and MERS epidemic. Asian Pac J Allergy Immunol [Internet]. 2020 Mar;38(1):1-9. Available from: http://dx.doi.org/10.12932/AP200220-0772

4. Shereen MA, Khan S, Kazmi A, Bashir N, Siddique R. COVID-19 infection: Origin, transmission, and characteristics of human coronaviruses. J Advert Res [Internet]. 2020 Jul;24:91-8. Available from: http://dx.doi.org/10.1016/j.jare.2020.03.005

5. Li F. Structure, Function, and Evolution of Coronavirus Spike Proteins. Annu Rev Virol [Internet]. 2016 Sep 29;3(1):237-61. Available from: http://dx.doi.org/10.1146/annurev-virology-110615-042301

6. Belouzard S, Millet JK, Licitra BN, Whittaker GR. Mechanisms of coronavirus cell entry mediated by the viral spike protein. Viruses [Internet]. 2012 Jun;4(6):1011-33. Available from: http:// dx.doi.org/10.3390/v4061011

7. Graham RL, Baric RS. Recombination, reservoirs, and the modular spike: mechanisms of coronavirus cross-species transmission. J Virol [Internet]. 2010 Apr;84(7):3134-46. Available from: http://dx.doi.org/10.1128/JVI.01394-09

8. Navas S, Seo SH, Chua MM, Das Sarma J, Lavi E, Hingley ST, et al. Murine coronavirus spike protein determines the ability of the virus to replicate in the liver and cause hepatitis. J Virol [Internet]. 2001 Mar;75(5):2452-7. Available from: http://dx.doi. org/10.1128/JVI.75.5.2452-2457.2001

9. Conti P, Ronconi G, Caraffa A, Gallenga C, Ross R, Frydas I, et al. Induction of pro-inflammatory cytokines (IL-1 and IL-6) and lung inflammation by Coronavirus-19 (COVI-19 or SARSCoV-2): anti-inflammatory strategies. J Biol Regul Homeost Agents [Internet]. 2020 Mar 14;34(2). Available from: http:// dx.doi.org/10.23812/CONTI-E

10. Liu Y-C, Kuo R-L, Shih S-R. COVID-19: The first documented coronavirus pandemic in history. Biomed J [Internet]. 2020 May 5; Available from: http://dx.doi.org/10.1016/j.bj.2020.04.007

11. Harsha L, Brundha MP. Prevalence of dental developmental anomalies among men and women and its psychological effect in a given population. Res J Pharm Biol Chem Sci [Internet]. 2017;9(6):869. Available from: http://search.proquest. com/openview/1f488cc6e377096f44a87e509aceab79/1?pqorigsite $=$ gscholar $\& \mathrm{cbl}=54977$

12. Shreya S, Brundha MP. Alteration of Haemoglobin Value in Relation to Age, Sex and Dental Diseases-A Retrospective Correlation Study. Research Journal of Pharmacy and Technology [Internet]. 2017;10(5):1363-6. Available from: http://www.indianjournals.com/ijor.aspx ?target $=$ ijor:rjpt\&volume $=10 \&$ issue $=5$ \&article $=016$

13. Ravichandran H, Brundha MP. Awareness about personal protective equipments in hospital workers (sweepers and cleaners). International Journal of Pharmaceutical Sciences Review and Research. 2016;40(1):28-9.

14. Mosaddeghi P, Negahdaripour M, Dehghani Z, Farahmandnejad M, Moghadami M, Nezafat N, et al. Therapeutic approaches for COVID-19 based on the dynamics of interferon-mediated immune responses. 2020; Available from: https://www.preprints. org/manuscript/202003.0206

15. Shenoy PB, Brundha MP. Awareness of polycystic ovarian disease among females of age group 18-30 years. Res J Pharm Biol Chem Sci [Internet]. 2016;8(8):813. Available from: http:// 
search.proquest.com/openview/a8a09e7b2e9d2f967bf3fee479c 7018a/1?pq-origsite $=$ gscholar\&cbl $=54977$

16. Brundha MP, Pathmashri VP, Sundari S. Quantitative Changes of Red Blood cells in Cancer Patients under Palliative Radiotherapy-A Retrospective Study. Research Journal of Pharmacy and Technology [Internet]. 2019;12(2):687-92. Available from: http://www.indianjournals.com/ijor.aspx?target=ijor:rjpt\&volu $\mathrm{me}=12$ \&issue $=2$ \&article $=041$

17. Kalaiselvi R, Brundha MP. Prevalence of hysterectomy in South Indian population. Research Journal of Pharmacy and Technology [Internet]. 2016;9(11):1941-4. Available from: http://www. indianjournals.com/ijor.aspx?target $=$ ijor:rjpt $\&$ volume $=9 \&$ issue $=11 \&$ article $=027$

18. Bokadia GS, Sneha. Bokadia G, Brundha MP, Ariga P. Current knowledge about lung cancer amongmiddleaged non medical males a questionnaire based survey [Internet]. Vol. 11, Research Journal of Pharmacy and Technology. 2018. p. 2565. Available from: http://dx.doi.org/10.5958/0974-360x.2018.00474.2

19. Swetha S, Brundha MP. Analysis of knowledge about the hospital warning symbols among the postgraduate dental studentsA comparative study [Internet]. Vol. 10, Research Journal of Pharmacy and Technology. 2017. p. 975. Available from: http:// dx.doi.org/10.5958/0974-360x.2017.00177.9

20. Varshini A, Rani SL, Brundha MP. Awareness of annual doctor checkups among general population. Drug Invention Today. 2020;14(2).

21. Preethikaa S, Brundha MP. Awareness of diabetes mellitus among general population. Research Journal of Pharmacy and Technology [Internet]. 2018;11(5):1825-9. Available from: http://www.indianjournals.com/ijor.aspx?target=ijor:rjpt\&volu me $=11$ \&issue $=5$ \&article $=024$

22. Timothy CN, Samyuktha PS, Brundha MP. Dental pulp Stem Cells in Regenerative Medicine--A Literature Review. Research Journal of Pharmacy and Technology [Internet]. 2019;12(8):4052-6. Available from: http://www.indianjournals.com/ijor.aspx?target $=$ ijor:rjpt $\&$ volume $=12 \&$ issue $=8 \&$ artic le $=088$

23. Hannah R, Ramani P, Brundha MP. Liquid Paraffin as a Rehydrant for Air Dried Buccal Smear. Research Journal of [Internet]. 2019; Available from: http://www.indianjournals.com/ijor. aspx?target $=$ ijor:rjpt \&volume $=12$ \&issue $=3$ \&article $=038$

24. Bandurska K, Krol I, Myga-Nowak M. Interferons: between structure and function. Postepy Hig Med Dosw [Internet]. 2014; Available from: https://europepmc.org/abstract/med/24864095

25. Meyer O. Interferons and autoimmune disorders. Joint Bone Spine [Internet]. 2009 Oct;76(5):464-73. Available from: http:// dx.doi.org/10.1016/j.jbspin.2009.03.012

26. Price GE, Gaszewska-Mastarlarz A, Moskophidis D. The role of alpha/beta and gamma interferons in development of immunity to influenza A virus in mice. J Virol [Internet]. 2000 May;74(9):3996-4003. Available from: http://dx.doi. org/10.1128/jvi.74.9.3996-4003.2000

27. Ealick SE, Cook WJ, Vijay-Kumar S, Carson M, Nagabhushan TL, Trotta PP, et al. Three-dimensional structure of recombinant human interferon-gamma. Science [Internet]. 1991 May 3;252(5006):698-702. Available from: http://dx.doi. org/10.1126/science.1902591

28. Borden EC, Sen GC, Uze G, Silverman RH, Ransohoff RM, Foster GR, et al. Interferons at age 50: past, current and future impact on biomedicine. Nat Rev Drug Discov [Internet]. 2007 Dec;6(12):975-90. Available from: http://dx.doi.org/10.1038/ $\operatorname{nrd} 2422$

29. Haritha PS, Brundha MP. Awareness of dengue fever among the parents of children coming to the dental outpatient depart- ment - A questionnaire study. International Journal of Clinicopathological Correlation [Internet]. 2019 Jul 1 [cited 2020 Jun 10];3(2):60. Available from: http://www.ijcpc.org/article. asp?issn $=2589-1731$; year $=2019$; volume $=3$; issue $=2$; spage $=60 ; \mathrm{e}$ page $=63$; aulast $=$ Haritha

30. Ali S, Mann-Nüttel R, Schulze A, Richter L, Alferink J, Scheu S. Sources of Type I Interferons in Infectious Immunity: Plasmacytoid Dendritic Cells Not Always in the Driver's Seat. Front Immunol [Internet]. 2019 Apr 12;10:778. Available from: http:// dx.doi.org/10.3389/fimmu.2019.00778

31. Brundha MP. A Comparative Study-The Role of Skin and Nerve Biopsy in Hansen's Disease. Journal of Pharmaceutical Sciences and Research. 2015;7(10):837-44.

32. Hoffmann H-H, Schneider WM, Rice CM. Interferons and viruses: an evolutionary arms race of molecular interactions. Trends Immunol [Internet]. 2015 Mar;36(3):124-38. Available from: http://dx.doi.org/10.1016/j.it.2015.01.004

33. Gavegnano C, Schinazi RF. Targeting JAK-STAT Pathway for Various Inflammatory Diseases and Viral Infections [Internet]. JAK-STAT Signaling in Diseases. 2020. p. 257-68. Available from: http://dx.doi.org/10.1201/9781351042468-14

34. Balaji S, Brundha MP, Path DNB. Awareness of About Breast Cancer among Dental Surgeons. Res J Pharm Biol Chem Sci. 2016;8(8):797.

35. Brierley MM, Fish EN. Review: IFN- $\alpha / \beta$ Receptor Interactions to Biologic Outcomes: Understanding the Circuitry. J Interferon Cytokine Res [Internet]. 2002 Aug 1;22(8):835-45. Available from: https://doi.org/10.1089/107999002760274845

36. Ferdioz J, Brundha MP. Awareness of stye. International Journal of Pharmaceutical Sciences Review and Research [Internet]. 2016 Jan 1 [cited 2020 Jun 8];40(1):30-2. Available from: http:// dx.doi.org/

37. Thäle C, Kiderlen AF. Sources of interferon-gamma (IFN-gamma) in early immune response to Listeria monocytogenes. Immunobiology [Internet]. 2005;210(9):673-83. Available from: http://dx.doi.org/10.1016/j.imbio.2005.07.003

38. Schroder K, Hertzog PJ, Ravasi T, Hume DA. Interferon- $\gamma$ : an overview of signals, mechanisms and functions [Internet]. Vol. 75, Journal of Leukocyte Biology. 2004. p. 163-89. Available from: http://dx.doi.org/10.1189/jlb.0603252

39. Medzhitov R. Inflammation 2010: new adventures of an old flame. Cell [Internet]. 2010 Mar 19;140(6):771-6. Available from: http://dx.doi.org/10.1016/j.cell.2010.03.006

40. Chen GY, Nuñez G. Sterile inflammation: sensing and reacting to damage. Nat Rev Immunol [Internet]. 2010 Dec;10(12):82637. Available from: http://dx.doi.org/10.1038/nri2873

41. Broz P, Dixit VM. Inflammasomes: mechanism of assembly, regulation and signalling. Nat Rev Immunol [Internet]. 2016 Jul;16(7):407-20. Available from: http://dx.doi.org/10.1038/ nri. 2016.58

42. Akira S, Uematsu S, Takeuchi O. Pathogen recognition and innate immunity. Cell [Internet]. 2006 Feb 24;124(4):783-801. Available from: http://dx.doi.org/10.1016/j.cell.2006.02.015

43. Medzhitov R. Recognition of microorganisms and activation of the immune response. Nature [Internet]. 2007 Oct 18;449(7164):819-26. Available from: http://dx.doi. org/10.1038/nature 06246

44. Malmgaard L. Induction and regulation of IFNs during viral infections. J Interferon Cytokine Res [Internet]. 2004 Aug;24(8):439-54. Available from: http://dx.doi. org/10.1089/1079990041689665

45. Samuel CE. Antiviral actions of interferons. Clin Microbiol Rev [Internet]. 2001 Oct;14(4):778-809, table of contents. Available from: http://dx.doi.org/10.1128/CMR.14.4.778-809.2001 
46. Le Page C, Génin P, Baines MG, Hiscott J. Interferon activation and innate immunity. Rev Immunogenet [Internet]. 2000;2(3):374-86. Available from: https://www.ncbi.nlm.nih. gov/pubmed/11256746

47. Kumar MD, Brundha MP. Awareness about nocturia-A questionnaire survey. Research Journal of Pharmacy and Technology [Internet]. 2016;9(10):1707-9. Available from: http://www. indianjournals.com/ijor.aspx?target $=$ ijor:rjpt $\&$ volume $=9 \&$ issue $=10$ \&article $=043$

48. Tau G, Rothman P. Biologic functions of the IFN-gamma receptors. Allergy [Internet]. 1999 Dec;54(12):1233-51. Available from: http://dx.doi.org/10.1034/j.1398-9995.1999.00099.x

49. Bot A, Bot S, Bona CA. Protective role of gamma interferon during the recall response to influenza virus. J Virol [Internet]. 1998 Aug;72(8):6637-45. Available from: https://www.ncbi. nlm.nih.gov/pubmed/9658110

50. Drapier J-C, Wietzerbin J, Hibbs JB Jr. Interferon- $\gamma$ and tumor necrosis factor induce the L-arginine-dependent cytotoxic effector mechanism in murine macrophages. Eur J Immunol [Internet]. 1988;18(10):1587-92. Available from: https://onlinelibrary.wiley.com/doi/abs/10.1002/eji.1830181018

51. Billiau A. Interferon- $\gamma$ : Biology and Role in Pathogenesis [Internet]. Advances in Immunology. 1996. p. 61-130. Available from: http://dx.doi.org/10.1016/s0065-2776(08)60428-9

52. Hensley LE, Fritz LE, Jahrling PB, Karp CL, Huggins JW, Geisbert TW. Interferon-beta 1a and SARS coronavirus replication. Emerg Infect Dis [Internet]. 2004 Feb;10(2):317-9. Available from: http://dx.doi.org/10.3201/eid1002.030482

53. Channappanavar R, Fehr AR, Zheng J, Wohlford-Lenane C, Abrahante JE, Mack M, et al. IFN-I response timing relative to virus replication determines MERS coronavirus infection outcomes. J Clin Invest [Internet]. 2019 Sep;129(9):3625-39. Available from: https://doi.org/10.1172/JCI126363

54. Bach EA, Aguet M, Schreiber RD. The IFN gamma receptor: a paradigm for cytokine receptor signaling. Annu Rev Immunol [Internet]. 1997;15:563-91. Available from: http://dx.doi. org/10.1146/annurev.immunol.15.1.563

55. Boehm U, Klamp T, Groot M, Howard JC. Cellular responses to interferon- $\gamma$. Annu Rev Immunol [Internet]. $1997 \mathrm{Apr}$ 1;15(1):749-95. Available from: https://doi.org/10.1146/annurev.immunol.15.1.749

56. Fantuzzi G, Reed DA, Dinarello CA. IL-12-induced IFN-gamma is dependent on caspase-1 processing of the IL-18 precursor J Clin Invest [Internet]. 1999 Sep;104(6):761-7. Available from: http://dx.doi.org/10.1172/JCI7501

57. Kopitar-Jerala N. The Role of Interferons in Inflammation and Inflammasome Activation. Front Immunol [Internet]. 2017 Jul 25;8:873. Available from: http://dx.doi.org/10.3389/fimmu.2017.00873

58. Brundha MP, Nallaswamy D. Hide and seek in pathology- A research on game-based histopathology learning. IJRPS [Internet]. 2019 Apr 29 [cited 2020 Jun 4];10(2):1410-4. Available from: https://www.pharmascope.org/index.php/ijrps/article/view/606

59. Prashaanthi N, Brundha MP. A Comparative Study between Popplet Notes and Conventional Notes for Learning Pathology. Research Journal of Pharmacy and Technology [Internet]. 2018;11(1):175-8. Available from: http://www.indianjournals. com/ijor.aspx?target $=$ ijor:rjpt $\&$ volume $=11 \&$ issue $=1 \&$ artic le $=032$ 